\title{
Complex Patterns, Unpredictable Consequences: The Distribution of Sealed Land along the Urban-rural Gradient in Barcelona Province
}

\author{
Flavia Ranalli \\ Luca Salvati \\ Consiglio per la Ricerca in Agricoltura e l'analisi dell'economia agraria (CRA) \\ flavia.ranalli@entecra.it \\ bayes00@yahoo.it
}

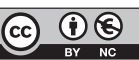

Received: April 2013

Accepted: January 2015

\begin{abstract}
The present study explores the spatial pattern of selected soil sealing indicators in the province of Barcelona as a contribution to the debate on land consumption driven by urban growth in southern Europe. Four indicators of soil sealing (percentage of pervious land, per-capita sealed land, soil sealing intensity and diversity in soil sealing intensity) were derived from a high-resolution topographic map at the municipal scale using multivariate statistics and spatial analysis. All the indicators were correlated with the distance from Barcelona. Our results show that sealing patterns in Barcelona reflect distinct urbanization phases observed in the aftermath of World War II and may describe the rapid transition from a mono-centric and compact form observed in the 1950 s to a more scattered and dispersed morphology. Soil sealing indicators proved to be effective proxies for the assessment of land-use changes in Mediterranean urban regions.
\end{abstract}

Keywords: Compact city; land use; exploratory statistics; urban sprawl; Barcelona.

Resum. Complexitat espacial, conseqüències impredictibles: la distribució de terres impermeables a través del gradient urbà-rural a la provincia de Barcelona

El patró espacial dels indicadors seleccionats de segellament del sòl s'ha explorat a la província de Barcelona com una contribució al debat sobre el consum de sòl impulsat per la urbanització a l'Europa mediterrània. Mitjançant l'ús de tècniques d'exploració multidimensional i d'anàlisi espacial, s'han obtingut indicadors de segellament del sòl (percentatge de sòl permeable, terrenys impermeables per càpita, intensitat de segellament del sòl i diversitat en la intensitat del segellament del sòl) a partir d'un mapa d'alta resolució del sòl en l'escala municipal. Tots els indicadors es van correlacionar amb la distància des del centre de Barcelona. Els resultats suggereixen que el patró de segellament del sòl a Barcelona reflecteix les diferents fases d'urbanització observades després de la Segona Guerra Mundial i indiquen la ràpida transició d'una forma urbana monocèntrica i compacta observada en la dècada dels anys cinquanta del segle passat a una aglomeració més dispersa. L'article tracta sobre l'ús d'indicadors d'impermeabilitat per a l'avaluació dels canvis d'ús del sòl a les grans regions urbanes mediterrànies.

Paraules clau: ciutat compacta; ús del sòl; tècniques estadístiques exploratòries; expansió urbana; Barcelona. 
Resumen. Complejidad espacial, consecuencias impredecibles: la distribución de tierras impermeables a través del gradiente urbano-rural en la provincia de Barcelona

El patrón espacial de los indicadores seleccionados de sellado del suelo se ha explorado en la provincia de Barcelona como una contribución al debate sobre el consumo de suelo impulsado por la urbanización en la Europa mediterránea. Mediante el uso de técnicas de exploración multidimensional y de análisis espacial, se han obtenido indicadores de sellado del suelo (porcentaje de suelo permeable, terrenos impermeables per cápita, intensidad de sellado del suelo y diversidad en la intensidad del sellado del suelo) a partir de un mapa del suelo urbano sellado en la escala municipal. Todos los indicadores se correlacionaron con la distancia desde el centro de Barcelona. Los resultados sugieren que el patrón de sellado del suelo en Barcelona refleja las distintas fases de urbanización observadas después de la Segunda Guerra Mundial e indican la rápida transición de una forma urbana monocéntrica y compacta observada en la década de los años cincuenta del siglo pasado a una aglomeración más dispersa. El artículo trata sobre el uso de indicadores de impermeabilidad para la evaluación de los cambios de uso del suelo en las grandes regiones urbanas mediterráneas.

Palabras clave: ciudad compacta; uso del suelo; técnicas estadísticas exploratorias; expansión urbana; Barcelona.

Résumé. Complexité spatiale et conséquences imprévisibles: la distribution des terres imperméables à travers le gradient urbain-rural dans la province de Barcelone

La répartition spatiale des indicateurs sélectionnés de l'imperméabilisation des sols a été explorée dans la province de Barcelone en tant que contribution au débat sur la consommation de terres entraînée par l'urbanisation dans le sud de l'Europe. En utilisant des techniques exploratoires multidimensionnelles et d'analyse spatiale, les indicateurs de l'imperméabilisation des sols (pourcentage des terres perméables, terres imperméables par habitant, intensité de l'imperméabilisation des sols et diversité de l'intensité de l'imperméabilisation des sols) ont été calculés à partir d'une carte à haute résolution du territoire à l'échelle municipale. Tous les indicateurs ont été corrélés avec la distance du centre de Barcelone. Les résultats suggèrent que l'imperméabilisation des sols à Barcelone reflète les différentes phases d'urbanisation observées après la Deuxième Guerre mondiale et ils indiquent le passage d'une forme urbaine monocentrique et compacte observée dans les années 1950 à une agglomération plus dispersée. L'article traite de l'utilisation des indicateurs d'imperméabilité pour l'évaluation des changements dans l'utilisation des sols dans les grandes régions urbaines méditerranéennes.

Mots-clés: ville compacte; utilisation des terres; techniques statistiques exploratoires; étalement urbain; Barcelone.

\section{Summary}
1. Introduction
4. Discussion
2. Methods
5. Conclusions
3. Results
Bibliographic references 


\section{Introduction}

Soil sealing is a form of land consumption that determines the loss of natural resources due to land covering for housing and infrastructures. A soil can be considered as sealed when irreversible changes in the physical condition of the permeable layer have occurred. Soil sealing increases the vulnerability of landscape to climate change, erosion, forest fires and water shortage (Johnson, 2001; Byrne et al., 2007), as well as contributing to the fragmentation of pristine habitats and the loss of fertile soil, thus determining changes in the hydrological cycle at the local scale (Ramos et al., 2000).

In ecologically-fragile landscapes found in southern Europe (Salvati, 2013a), the spatial distribution of impervious land has traditionally been determined by the action of several factors from the local to the regional scale (Serra et al., 2008). Geographical gradients (e.g. elevation, coastal-inland) can be strongly influenced by socioeconomic variables (Munafo et al., 2010). Although Mediterranean cities are usually considered compact and dense (European Environment Agency [EEA], 2011), soil sealing has increased in peri-urban areas due to settlement expansion and the economic consolidation of medium-sized cities (Alphan, 2003; Polyzos et al., 2008; Schneider and Woodcock, 2008; Kucukmehmetoglu and Geymen, 2009; Yilmaz, 2010).

The permanent assessment of impervious land is a useful tool for analyzing natural resources and evaluating urban morphological changes (Weber et al., 2005; Christopoulou et al., 2007; Doygun et al., 2008). While some negative externalities of soil sealing are well known and measured, it is necessary to recognize that different urban expansion typologies have different implications as well. The positive impacts of low-density urbanization may be due to larger areas of private gardens that improve soil water infiltration, thus mitigating the heat island effect and improving biodiversity conservation as compared to more dense urban forms (Alberti, 2005).

Quantitative approaches based on high-resolution soil sealing monitoring capable of identifying different suburban morphologies (e.g. by distinguishing different sealing density levels) are particularly important in this context. Monitoring the spatial evolution of soil sealing in relation to different urbanization phases and the changing spatial organization of cities also supports sustainable planning and land management in peri-urban regions (Neuman, 2005).

Quantitative approaches to map changes in city form and urban land uses have recently been proposed (Kilic et al., 2006; Catalàn et al., 2008; Schneider and Woodcock, 2008; Cabral et al., 2011; Reckien et al., 2011; Villa, 2012). Although a set of indicators has been introduced to monitor the increase in the surface area of sealed land (Hasse and Lathrop, 2003; García Rodríguez and Pérez González, 2007; Chorianopoulos et al., 2010; Jaeger et al., 2010), calculating these indicators requires data which may be of limited availability (Giannakourou, 2005). The present study applies the approach proposed by Salvati (2013b) to estimate local-scale soil sealing in Barcelona province using a multi-dimensional analysis of imperviousness indicators extracted from a 
high-resolution sealing map (EEA, 2011). The selected indicators are intended to provide a comprehensive assessment of sealing patterns in the study area (Hasse and Lathrop, 2003; Jaeger et al., 2010; Munafo et al., 2010) and estimate land-use efficiency, land fragmentation, sealing intensity and diversity in spatial patterns.

The study tests the hypothesis that land-use efficiency (in terms of per-capita sealed land), landscape fragmentation (in terms of the spatial distribution of unsealed land), sealing intensity and the diversification of soil sealing spatial patterns are influenced by the urban-rural gradient (Polyzos et al., 2008). The procedure has been applied to the province of Barcelona; a compact city developing towards urban scattering (Catalàn et al., 2008; Garcia-Lopez and Muñiz, 2010). The results of this study provide useful information for sealing containment which can be extended to other 'sprawling' cities in both developed and developing countries.

\section{Methods}

\subsection{Study area}

The study area comprises the administrative province of Barcelona including the metropolitan area (AMB), which spans a total of 311 local municipalities and a surface area of $7.726 \mathrm{~km}^{2}$. Rapid population growth was observed in the region after World War II with growth rates of above $2 \%$ per year in the 'demographic boom' period. Although urban areas occupy a significant and increasing portion of the region and have quadrupled over the last 50 years, almost $60 \%$ of the area still consists of semi-natural and natural land covers such as cropland, pastures and woodlands. The province is characterized by heterogeneous landscapes, with elevations ranging from 0 to $1700 \mathrm{~m}$ a.s.l. and marked climatic gradients (Marull et al., 2010). The study area consists of nearly $30 \%$ lowlands, $40 \%$ uplands and $30 \%$ mountains. The coastal and pre-coastal landscape is comprised of natural and semi-natural habitats, while croplands, relict forest-crop mosaics and urban areas dominate lowlands (Marull et al., 2010).

The urban-rural gradient in the metropolitan area is laid out concentrically, where the municipality of Barcelona occupies a large and compact core, surrounded by a first dense metropolitan ring, a second extensive metropolitan ring and other municipalities that are more independent and act as sub-centres (Catalàn et al., 2008; Paül and Tonts, 2005).

\subsection{Geographical analysis}

Impervious surfaces are mainly pavement structures (roads, sidewalks, driveways and parking lots) covered by asphalt, concrete, brick, stone and rooftops (EEA, 2006). In 2009, as part of the Global Monitoring for Environment and Security (GMES) Fast Track Service on Land Monitoring, the EEA produced 


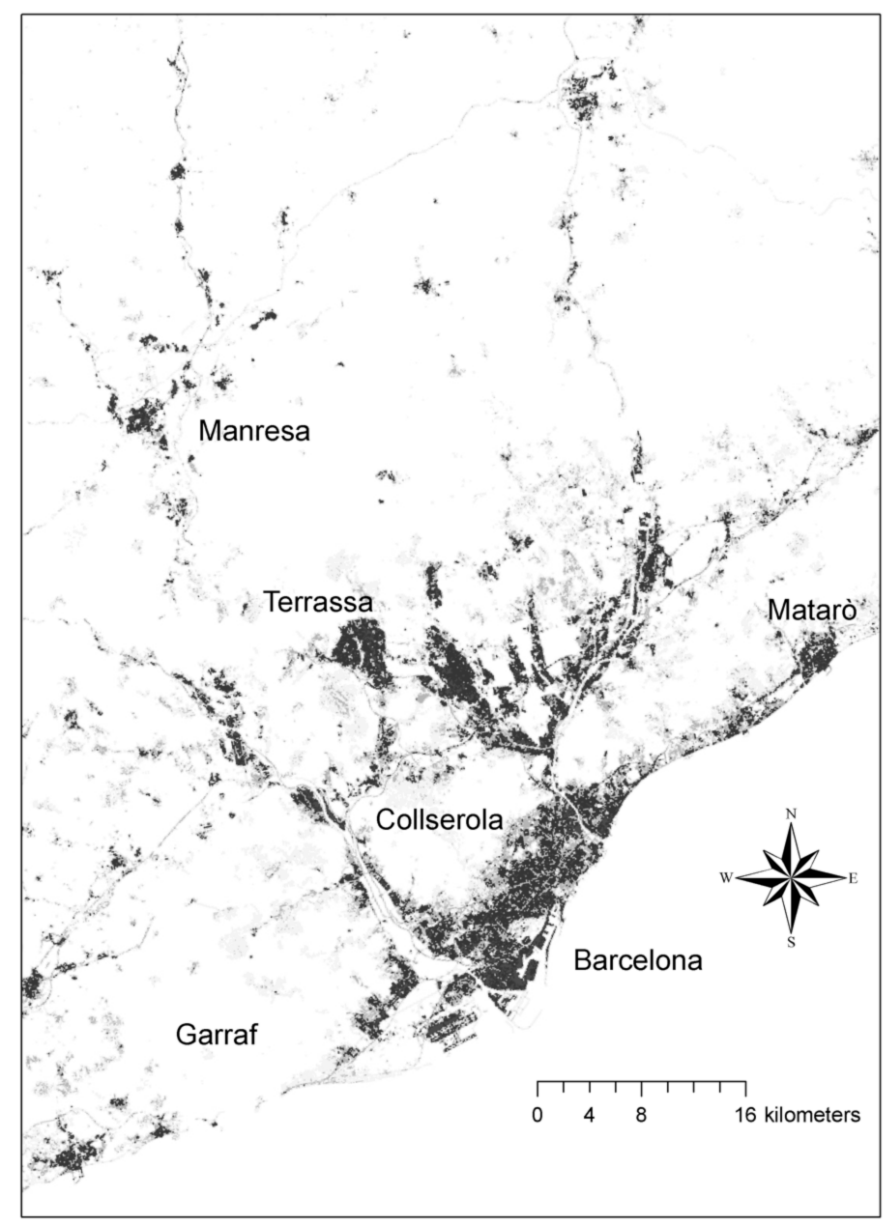

Figure 1. Map illustrating sealed soils in Barcelona area (2006). White indicates unsealed surfaces, progressively darker grey tonalities indicate increasing imperviousness rates, black represents totally sealed land.

Source: Authors based on European Environment Agency data.

a raster dataset of built-up and non built-up areas including continuous degree of soil sealing ranging from $0 \%$ to $100 \%$ in $100 \times 100 \mathrm{~m}$ spatial resolution (Figure 1) with European coverage. Multi-sensor and bi-temporal, orthorectified satellite imagery was used to collect soil sealing data in the same manner as the CORINE Land Cover 2006 cartography (IMAGE2006) covering 38 European countries. The map, which is freely available in GeoTiff format, refers to 2006 and we consider it particularly detailed, representative and homogeneous at the European scale (EEA, 2011). 
High-resolution Google Earth imagery was used as a supplementary dataset to validate the EEA soil sealing map. Reference sealing percentages were obtained using a $10 \times 10 \mathrm{~m}$ grid positioned around the sampling points. Classification accuracy was checked by estimating omission error, commission error and overall accuracy. Classification accuracy of built-up and non built-up areas is higher than $85 \%$ per hectare and both omission and commission errors are below 15\% (EEA, 2011). According to the descriptive statistics derived from the map, $6.5 \%$ of the European territory was covered by 1 ha cells including sealing (any percentage between 1\% and 100\%) in 2006 .

In this study, the minimum spatial unit of analysis is represented by the local municipal boundaries. Although local administrative boundaries provide arbitrary units of measurement, they have been used as the denominator for demographic and land-use change analysis in both quantitative applications and qualitative case studies (Garcia and Riera, 2003; Tsai, 2005; Munafò et al., 2010). Because municipalities are the spatial scale at which urban planning policies are defined and most development decisions are taken, they play a key role in explaining the observed results and differences between municipalities. The composition of sealed land in each municipality was calculated according to the degree of imperviousness measured in each cell of the raster map using the 'Tabulate area' tool provided with ArcGIS (ESRI Inc., Redwoods, USA) after the overlap between the soil sealing map and the shapefile containing the municipalities' boundaries provided by the Spanish National Institute of Statistics (INE).

\subsection{Statistical analysis}

Six proxies of soil sealing were derived at the municipal scale from the aforementioned EEA high-resolution map (Table 1). Four supplementary variables (population density in 2010, annual population growth rate in the period 2000-2010, annual population growth rate in the period 1980-2010 and distance $(\mathrm{km})$ from the city centre of Barcelona: Plaça Catalunya) were also calculated at the municipal scale. The supplementary variables were derived from official statistics provided by INE. Among sealing indicators, per-capita sealed land (PRO) should be considered a gross measurement of per-capita soil consumption as it jointly considers the total urbanized surface (including the residential fabric formed by second homes and industrial, commercial and service areas) and the residential population registered in every municipality.

The relationship between the selected soil sealing indicators and distance from the centre of Barcelona was analyzed through parametric (Pearson) and non-parametric (Spearman) correlation coefficient tests at $p<0.001$. The Pearson and Spearman correlation coefficients allow checking for normality and linearity in the study variables and relationships, respectively. The correlation between the soil sealing indicators and the population variables was calculated by Spearman non-parametric cograduation rank tests using STATISTICA (STAT Software Inc., Tulsa, Oklahoma, USA). After Bonferroni correction 
for multiple comparisons, significance was tested at $p<0.001$. Finally, to identify latent patterns in the distribution of sealed land in Barcelona, principal component analysis (PCA) was performed on the data matrix composed of the 311 municipalities (rows) and 9 indicators listed in Table 1. As the PCA was

Table 1. List of soil sealing indicators (according to Salvati, 2013) and ancillary variables considered in the study (*indicates indicators acting as supplementary variables in the principal components analysis)

\begin{tabular}{|c|c|c|c|c|}
\hline \multicolumn{5}{|c|}{ Soil sealing indicators } \\
\hline Acronym & Variable & $\begin{array}{l}\text { A brief description of the } \\
\text { indicator }\end{array}$ & $\begin{array}{l}\text { Unit of measure } \\
\text { (range) }\end{array}$ & Source \\
\hline INT & $\begin{array}{l}\text { Average soil sealing } \\
\text { intensity index weighted by } \\
\text { the surface land of each } \\
\text { imperviousness class }\end{array}$ & $\begin{array}{l}\text { Provides information on } \\
\text { dispersed urban forms and } \\
\text { land consumption patterns }\end{array}$ & $\%(0-100)$ & $\begin{array}{l}\text { EEA soil sealing raster } \\
\text { map }\end{array}$ \\
\hline PER & $\begin{array}{l}\text { Percentage of pervious land } \\
\text { (i.e. land classified at } 0 \% \\
\text { imperviousness) }\end{array}$ & $\begin{array}{l}\text { Evaluates habitat fragmenta- } \\
\text { tion and the possible impact } \\
\text { of soil sealing on the hydrolo- } \\
\text { gical cycle }\end{array}$ & $\%(0-100)$ & $\begin{array}{l}\text { EEA soil sealing raster } \\
\text { map }\end{array}$ \\
\hline PRO & Per-capita sealed land & $\begin{array}{l}\text { Estimates the efficiency in } \\
\text { the use of land }\end{array}$ & $m^{2}(0-\infty)$ & $\begin{array}{l}\text { EEA sealing map and } \\
\text { population by } \\
\text { municipalities (INE) }\end{array}$ \\
\hline EVE & $\begin{array}{l}\text { Heterogeneity in } \\
\text { imperviousness level } \\
\text { calculated as the Pielou's } \\
\text { eveness index based on } \\
\text { the Shannon diversity index }\end{array}$ & $\begin{array}{l}\text { Identifies municipalities with } \\
\text { urban functions characterized } \\
\text { by high diversity in } \\
\text { imperviousness level }\end{array}$ & $\begin{array}{l}\text { (0: low heteroge- } \\
\text { neity to } 1: \text { high } \\
\text { heterogeneity) }\end{array}$ & $\begin{array}{l}\text { EEA soil sealing raster } \\
\text { map }\end{array}$ \\
\hline $\operatorname{RAP}\left({ }^{\star}\right)$ & $\begin{array}{l}\text { The ratio of INT to total } \\
\text { impervious land } \\
\text { (i.e. 100-PER) }\end{array}$ & A proxy of urban compactness & $\begin{array}{l}\text { (0: dispersed to } \\
1: \text { compact) }\end{array}$ & $\begin{array}{l}\text { EEA soil sealing raster } \\
\text { map }\end{array}$ \\
\hline $\operatorname{cov}\left({ }^{\star}\right)$ & $\begin{array}{l}\text { The number of impervious- } \\
\text { ness classes observed in } \\
\text { each municipality }\end{array}$ & a supplementary variable & $\#$ & $\begin{array}{l}\text { EEA soil sealing raster } \\
\text { map }\end{array}$ \\
\hline \multicolumn{5}{|c|}{ Ancillary variables } \\
\hline Acronym & Variable & $\begin{array}{l}\text { A brief description of the } \\
\text { indicator }\end{array}$ & $\begin{array}{l}\text { Unit of measure } \\
\text { (range) }\end{array}$ & Source \\
\hline DEN & Population density & $\begin{array}{l}\text { Proxy of the urban-rural } \\
\text { gradient }\end{array}$ & $\begin{array}{l}\text { Inhabitants } / \mathrm{km}^{2} \\
(0-\infty)\end{array}$ & $\begin{array}{l}\text { Resident population } \\
\text { by municipalities (INE) }\end{array}$ \\
\hline VAR & $\begin{array}{l}\text { Annual demographic change } \\
(2000-2010)\end{array}$ & $\begin{array}{l}\text { Proxy for short- term } \\
\text { population dynamics }\end{array}$ & $\%(-\infty / \infty)$ & $\begin{array}{l}\text { Resident population } \\
\text { by municipalities (INE) }\end{array}$ \\
\hline VAL & $\begin{array}{l}\text { Annual demographic change } \\
(1980-2010)\end{array}$ & $\begin{array}{l}\text { Proxy for long- term } \\
\text { population dynamics }\end{array}$ & $\%(-\infty / \infty)$ & $\begin{array}{l}\text { Resident population } \\
\text { by municipalities (INE) }\end{array}$ \\
\hline DIS & $\begin{array}{l}\text { Distance from Barcelona } \\
\text { (Plaça Catalunya) }\end{array}$ & $\begin{array}{l}\text { A proxy for mono-centric } \\
\text { spatial organization of the } \\
\text { urban region }\end{array}$ & $\mathrm{km}(0-\infty)$ & $\begin{array}{l}\text { Spatial analysis on a } \\
\text { municipality bounda- } \\
\text { ries map provided by } \\
\text { INE, using the centroid }\end{array}$ \\
\hline SUP & Surface area of municipality & A control variable & $\mathrm{km}^{2}(0-\infty)$ & $\begin{array}{l}\text { Municipality bound- } \\
\text { aries map provided } \\
\text { by INE }\end{array}$ \\
\hline
\end{tabular}

Source: Authors based on European Environment Agency and INE data. 
based on the correlation matrix, the number of significant factors was chosen by retaining the components with eigenvalue $>1$ (Salvati et al., 2013).

\section{Results}

Of the total study area in 2006 (Figure 2), 14.7\% was impervious land (1\% to $100 \%$ imperviousness) with $6.1 \%$ average soil sealing intensity, thus determining a final ratio between the two variables (Rap) of 0.42 (Table 2). Rap indicates a predominance of land with intermediate and low imperviousness rates in Barcelona province. Land with a high imperviousness rate is concentrated along the coastal rim, especially in the main urban conurbation of the region formed by the municipalities of Barcelona, Badalona and El Prat de Llobregat. Per-capita impervious land reaches $86 \mathrm{~m}^{2}$, while the heterogeneity of soil sealing intensity, measured using Pielou's index at the municipal scale, amounts to 0.27 , thus indicating spatial polarization in land with high and low imperviousness rates.

The spatial distribution of the selected indicators in each municipality is illustrated in Figure 2. In general, all of the indicators show a marked urbanrural gradient, as clearly depicted by the population density gradient. By contrast, population variation showed distinct spatial patterns at the regional scale, with the highest increase being observed in peri-urban areas located between Barcelona and the inland mountainous areas. Population density patterns are clearly reflected in soil sealing intensity, which was found to be higher in the municipalities around Barcelona. However, the percentage of pervious land indicates a more fragmented pattern where unsealed areas alternate with medium and high impervious areas, irrespective of the distance from Barcelona. Per-capita sealed land follows a urban-rural gradient while Rap reveals a complex spatial distribution with the highest values associated to flat areas and the main urban centres of the region. The heterogeneity in sealing intensity, together with the number of imperviousness classes observed in each municipality, may indicate the area where urban functions concentrate. This area includes municipalities within a distance of $<20 \mathrm{~km}$ from the Mediterranean coast and municipalities located in the main valleys and along the roads leading to the Pyrenees.

Table 2. Average value of soil sealing indicators by selected geographical partitions of the study area

\begin{tabular}{ccccc}
\hline Variable & Barcelona & Metropolitan area & Other municipalities & Province \\
\hline INT & 55.8 & 22.3 & 4.4 & 6.1 \\
PRO & 80.5 & 43.6 & 12.0 & 14.7 \\
PER & 34 & 68 & 132 & 86 \\
EVE & 0.90 & 0.65 & 0.23 & 0.27 \\
RAP & 0.69 & 0.51 & 0.37 & 0.42 \\
\hline
\end{tabular}

Source: Authors based on European Environment Agency and INE data. 

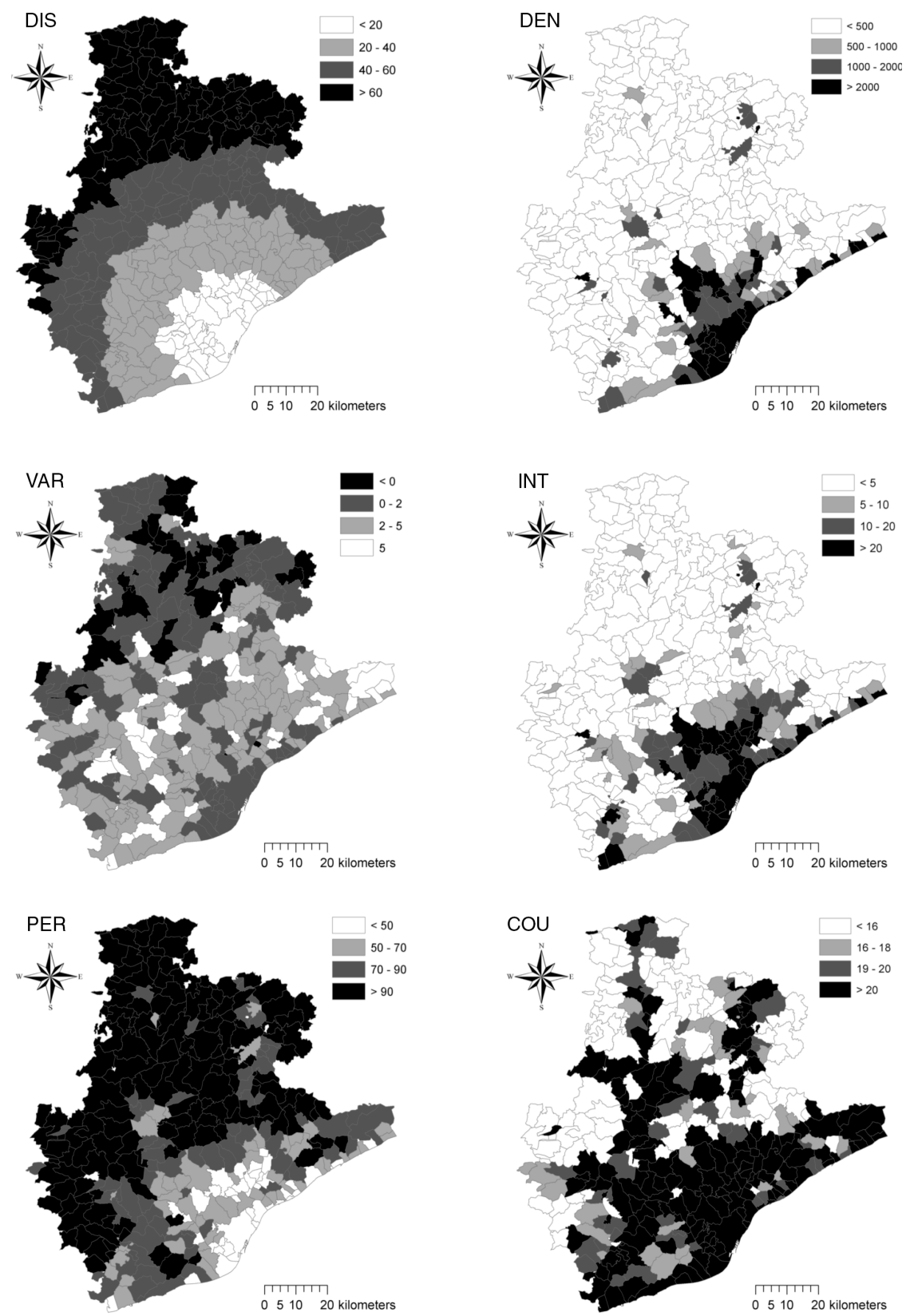

Figure 2. Spatial distribution of selected soil sealing indicators and additional variables in the municipalities of Barcelona province.

Source: Authors based on European Environment Agency and INE data. 
Using a traditional partition of the study area in the core city, the metropolitan area and the remaining municipalities (Table 2) showed that the high settlement compactness and density found in Barcelona was not observed in the metropolitan area, which ranks between the core city and the rural municipalities. This indicates the proportional influence of distance from the main urban centre on the spatial distribution of sealed land in Barcelona. This interpretation was confirmed by the analysis reported in Table 3. The average value of the selected indicators was calculated using defined distance classes from Barcelona. Interestingly, all the indicators follow an urban-rural gradient except for per-capita sealed land, which increases in a non-linear fashion with the distance from Barcelona.

Pair-wise correlations among the soil sealing indicators showed that the intensity rate correlated significantly with the percentage of pervious land, while per-capita sealed land was not associated to any other variable (Table 4). Interestingly, the heterogeneity in the distribution of sealing intensity at the municipal scale is correlated with the imperviousness rate. Comparable results were obtained from parametric and non-parametric techniques indicating linearity in the observed relation. The analysis with supplementary variables (Table 5) indicated that population density and distance from Barcelona are the only factors showing significant correlations with all the selected indicators except from per-capita sealed land.

The results of the PCA (Table 6) confirm the role of the urban gradient in the spatial distribution of sealed land. PCA extracted two factors with absolute

Table 3. Average value of soil sealing indicators by distance from the centre of Barcelona

\begin{tabular}{cccccccccc}
\hline Variable & $<10$ & $10-20$ & $20-30$ & $30-40$ & $40-50$ & $50-60$ & $60-70$ & $70-80$ & $>80$ \\
\hline INT & 38.0 & 22.6 & 10.7 & 5.3 & 4.2 & 2.6 & 1.1 & 1.0 & 0.5 \\
PER & 63.1 & 47.1 & 27.7 & 15.8 & 11.8 & 7.9 & 3.5 & 3.2 & 1.6 \\
PRO & 40 & 109 & 124 & 140 & 142 & 152 & 179 & 206 & 140 \\
EVE & 0.82 & 0.68 & 0.45 & 0.29 & 0.23 & 0.16 & 0.08 & 0.07 & 0.04 \\
RAP & 60.2 & 48.0 & 38.4 & 33.5 & 35.7 & 32.6 & 30.9 & 31.0 & 34.7 \\
\hline
\end{tabular}

Source: Authors based on European Environment Agency and INE data.

Table 4. Pair-wise correlation analysis between soil sealing indicators in Barcelona. Bold type indicates a significant relationship at $p<0.05$

\begin{tabular}{|c|c|c|c|c|c|c|c|c|c|c|}
\hline \multirow[b]{2}{*}{ Variable } & \multicolumn{5}{|c|}{ Pearson linear correlation coefficient } & \multicolumn{5}{|c|}{ Spearman rank correlation coefficient } \\
\hline & PER & RAP & PRO & $\mathrm{COU}$ & EVE & PER & RAP & PRO & $\mathrm{COU}$ & EVE \\
\hline INT & -0.95 & 0.82 & -0.21 & 0.45 & 0.89 & -0.99 & 0.83 & -0.07 & 0.83 & 0.99 \\
\hline PER & & -0.76 & 0.21 & -0.55 & -0.98 & & -0.73 & 0.08 & -0.77 & -1.00 \\
\hline RAP & & & -0.08 & 0.69 & 0.77 & & & -0.01 & 0.80 & 0.74 \\
\hline PRO & & & & 0.10 & -0.18 & & & & 0.15 & -0.09 \\
\hline $\mathrm{COU}$ & & & & & 0.63 & & & & & 0.77 \\
\hline
\end{tabular}

Source: Authors based on European Environment Agency and INE data. 
Table 5. Correlation analysis between soil sealing indicators and ancillary variables. Bold type indicates a significant relationship at $p<0.05$

\begin{tabular}{|c|c|c|c|c|c|c|c|c|c|c|}
\hline \multirow[b]{2}{*}{ Variable } & \multicolumn{5}{|c|}{ Pearson linear correlation coefficient } & \multicolumn{5}{|c|}{$\begin{array}{c}\text { Spearman non-parametric cograduation } \\
\text { coefficient }\end{array}$} \\
\hline & DEN & VAR & VAL & SUP & DIST & DEN & VAR & VAL & SUP & DIST \\
\hline INT & 0.83 & -0.10 & -0.07 & -0.36 & -0.56 & 0.96 & 0.16 & 0.28 & -0.54 & -0.68 \\
\hline PER & -0.73 & 0.00 & -0.02 & 0.45 & 0.63 & -0.96 & -0.21 & -0.34 & 0.56 & 0.71 \\
\hline RAP & 0.66 & -0.15 & -0.12 & -0.27 & -0.48 & 0.77 & -0.10 & -0.05 & -0.36 & -0.44 \\
\hline PRO & -0.24 & 0.01 & 0.02 & 0.13 & 0.20 & -0.29 & 0.08 & 0.03 & 0.19 & 0.19 \\
\hline $\mathrm{COU}$ & 0.28 & 0.18 & 0.11 & -0.17 & -0.51 & 0.76 & 0.16 & 0.20 & -0.18 & -0.52 \\
\hline EVE & 0.65 & 0.06 & 0.05 & -0.48 & -0.67 & 0.96 & 0.21 & 0.34 & -0.57 & -0.71 \\
\hline
\end{tabular}

Source: Authors based on European Environment Agency and INE data.

Table 6. Factor analysis results (italics indicate supplementary variables)

\begin{tabular}{lcc}
\hline Variable & Factor 1 & Factor 2 \\
\hline INT & 0.94 & 0.20 \\
PER & -0.97 & -0.06 \\
PRO & -0.30 & -0.03 \\
DEN & 0.79 & 0.28 \\
VAR & 0.05 & -0.92 \\
VAL & 0.08 & -0.90 \\
EVE & 0.95 & -0.02 \\
SUP & -0.51 & 0.15 \\
DIS & -0.73 & 0.36 \\
RAP & 0.77 & 0.23 \\
COU & 0.52 & -0.16 \\
\% variance & 47.3 & 21.3 \\
\hline
\end{tabular}

Source: Authors based on European Environment Agency and INE data.

eigenvalues higher than 1 that explain more than $68 \%$ of the total variance. Indicator loadings $>|0.5|$ were observed on both factors. Factor 1 explained $47 \%$ of the total variance and is positively associated to sealing intensity and negatively associated to the distance from Barcelona (Figure 3). Factor 2 identified municipalities with high population growth in the last period. Interestingly, these municipalities were not found to be associated with any soil sealing indicator, thus suggesting the dependence of imperviousness degree and percapita sealed land on the long-term urban expansion path. 


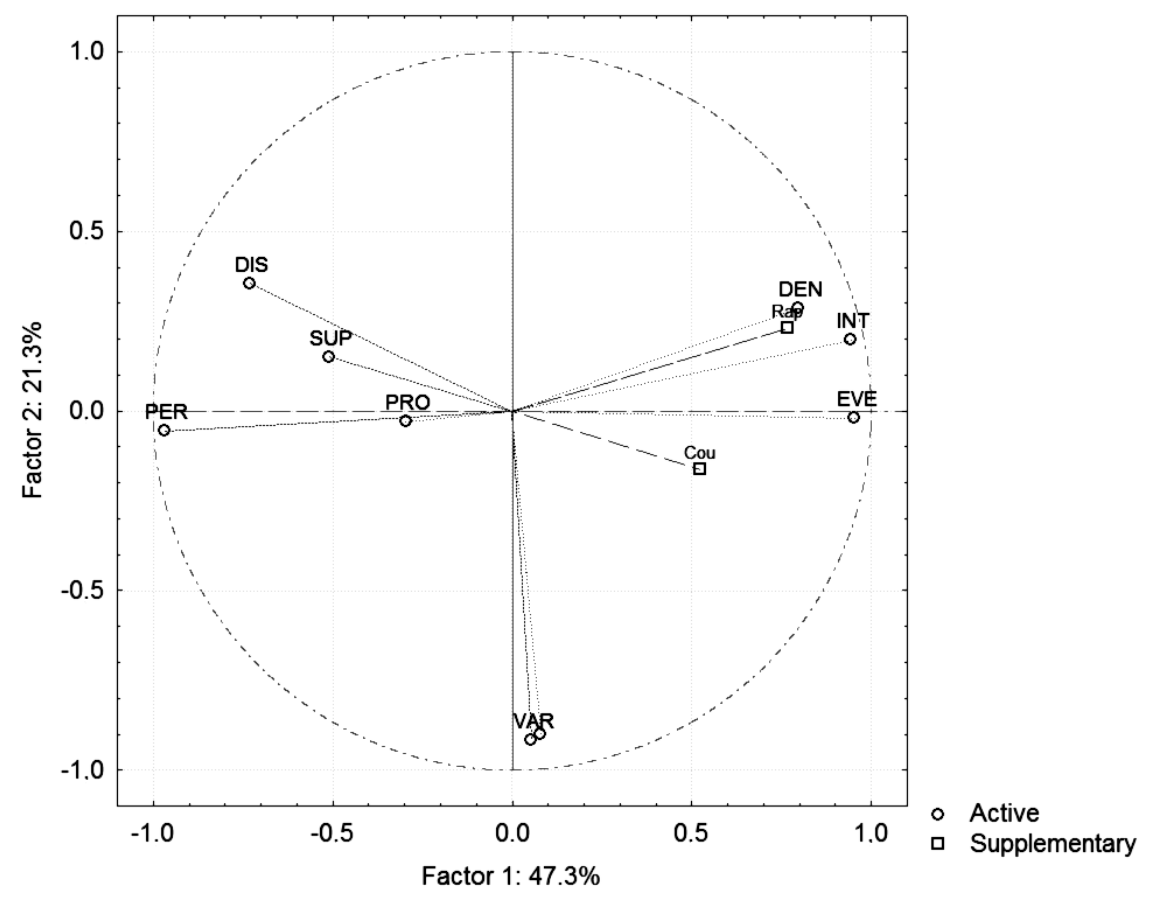

Figure 3. Factor loadings to the two main axes extracted by principal components analysis. Source: Authors based on European Environment Agency and INE data.

\section{Discussion}

This study contributes to urban studies and environmental geography by investigating the spatial distribution of sealed soils in a Mediterranean region characterized by an evident gradient shaped by long-term urban expansion. Exploratory analysis dealing with landscape transformation and rearrangements in peri-urban areas is particularly challenging in this context since urbanization is one of the most effective drivers of land-use changes worldwide. A set of indicators is thus proposed with the aim to assess different sealing dimensions, particularly spatial distribution, intensity and heterogeneity (Salvati, 2013b).

The results reveal a marked differentiation between municipalities featuring compact and dense settlements and municipalities in which the majority of land is unsealed. The former group is characterized by a high degree of imperviousness, high sealing intensity and low per-capita impervious land, while the latter group showed a low or negligible degree of imperviousness, low or medium-low sealing intensity and intermediate per-capita impervious land. These findings corroborate previous results observed in other large urban regions in Europe, especially in the Mediterranean region (see, for example, Catalàn et al., 2008; Munafo et al., 2010; Villa, 2012). 
Apart from the classical divergence between urban and rural municipalities, the results highlight the existence of an intermediate group of municipalities featuring intermediate sealing levels, medium-high per-capita impervious land and a relatively high diversification of sealing intensity. As suggested by Nel.lo (2011a), this may indicate that the process of urban spillover characterizing Barcelona's growth in the last thirty years has produced suburban spaces with moderately dispersed urban forms and morphological characteristics in-between urban and rural settlements (Couch et al., 2007). This process is reflected in the transformation of the landscape surrounding large urban regions into a rural-non-farm, fragmented and mixed landscape (Allen, 2003; Alberti, 2005, 2010; Aguilar, 2008). Interestingly, this phenomenon has been observed in strictly mono-centric cities (Alphan, 2003; Catalàn et al., 2008; Villa, 2012), dispersed and highly-fragmented cities (Doygun et al., 2008; Kucukmehmetoglu and Geymen, 2009; Salvati et al., 2013) and wider metropolitan regions suffering deregulated urban expansion (Shahraki et al., 2011).

Our results also suggest that compact growth and urban dispersion influence the soil sealing rate in a different manner. Contrary to continuous and dense urban expansion, exurban development produced a spatial rearrangement of land uses along the urban-rural gradient, thus determining higher land consumption and lower soil occupation efficiency measured in per capita terms (Paül and Tonts, 2005; McGregor et al., 2006; Salvati et al., 2013). Due to urban expansion, the impact of soil sealing is particularly intense in coastal and flat areas, where rapidly increasing human pressure has been observed (Serra et al., 2013). Infrastructure-driven pressure on land and changes in land prices along the fringe have been key drivers of soil sealing during the last two decades in Barcelona (Serra et al., 2008) and their role should be further investigated in new socioeconomic contexts determined by the economic crisis. Such rapid development of suburban areas requires a rethinking of the contemporary city towards more sustainable urban forms to promote sprawl containment, especially in cities where the urban-rural gap in population density is still evident (Nel.lo, 2011b).

\section{Conclusions}

This study indicates how proxies of natural and agricultural land fragmentation developed at the local scale and derived from high-resolution land-use maps may provide important insight for the analysis of urbanization-driven soil sealing. Our approach provides a coherent description of spatial soil sealing trends by identifying groups of municipalities with different imperviousness patterns. Suburban municipalities (including recently urbanized areas with low-density, dispersed settlements) are affected by intermediate sealing intensity, low sealing efficiency and diversification in sealing intensity. Given that soil is a fundamental resource for environmental stability and the continuity of human activities, all the processes that negatively influence soil functions justify the in-depth monitoring of sustainable land management practices (Ferrara et al., 2014). 
Planning measures to combat soil degradation in peri-urban and rural areas (Briassoulis, 2004) involve both urban planning and management of agricultural and pastoral practices (Kucukmehmetoglu and Geymen, 2009). The conservation of mixed agro-forest landscapes in these municipalities, which may be threatened by sealing intensity and heterogeneity, requires reflecting on the importance of compact and semi-dense settlement models to promote urban containment in the traditional landscapes of southern Europe.

\section{Bibliographic references}

Aguilar, A. G. (2008). "Peri-urbanization, illegal settlements and environmental impact in Mexico City". Cities. 25, 133-145.

Alberti, M. (2005). "The Effects of Urban Patterns on Ecosystem Function”. International Regional Science Review. 28(2), 168-192.

- (2010). "Maintaining ecological integrity and sustaining ecosystem function in urban areas". Current Opinion in Environmental Sustainability. 2, 178-184.

Allen, A. (2003). "Environmental planning and management of the peri-urban interface: perspectives on an emerging field". Environment \& Urbanization. 15(1), $135-147$.

Alphan, H. (2003). "Land use change and urbanisation of Adana, Turkey". Land Degradation and Development. 14, 575-586.

Briassoulis, H. (2004). "The institutional complexity of environmental policy and planning problems: the example of Mediterranean desertification". Journal of Environmental Planning Management. 47, 115-135.

Byrne, L. B. (2007). "Habitat structure: a fundamental concept and framework for urban soil ecology". Urban Ecosystems. 10, 255-274.

Cabral, P., Santos, J.A. and Augusto, G. (2011). "Monitoring urban sprawl and the national ecological reserve in Sintra-Cascais, Portugal: Multiple OLS linear regression model evaluation". Journal of Urban Planning and Development. 137, 346-353.

Catalàn, B., Sauri, D. and Serra, P. (2008). "Urban sprawl in the Mediterranean? Patterns of growth and change in the Barcelona Metropolitan Region 1993-2000). Landscape and Urban Planning. 85(3-4), 174-184.

Chorianopoulos, I., Pagonis, T., Koukoulas, S. and Drymoniti, S. (2010). "Planning, competitiveness and sprawl in the Mediterranean city: The case of Athens". Cities. 27, 249-259.

Christopoulou, O., Polyzos, S. and Minetos, D. (2007). "Peri-urban and urban forests in Greece: obstacle or advantage to urban development?". Journal of Environmental Management. 18, 382-395.

Couch, C., Petschel-held, G. and Leontidou, L. (2007). Urban Sprawl In Europe: Landscapes, Land-use Change and Policy. London: Blackwell.

Doygun, H., Alphan, H. and Gurun, D. K. (2008). "Analysing urban expansion and land use suitability for the city of Kahramanmaras, Turkey, and its surrounding region". Environmental Monitoring and Assessment. 145, 387-395.

European ENVIronment Agency (2006) Urban sprawl in Europe - The ignored challenge. Copenhagen: EEA Report no. 10.

- (2011). Urban soil sealing in Europe. Copenhagen: EEA <http://www.eea.europa.eu/articles/urban-soil-sealing-in-europe> and <http://www.eea.europa.eu/ 
data-and-maps/data/eea-fast-track-service-precursor-on-land-monitoring-degreeof-soil-sealing-100m-1> (accessed December 2012).

Ferrara, A., Salvati, L., Sabbi, A., Colantoni, A. (2014). "Soil resources, land cover changes and rural areas: Towards a spatial mismatch?". Science of The Total Environment, 478, 116-122.

García Rodríguez, P. and Pérez González, M. E. (2007). "Changes in soil sealing in Guadalajara (Spain): Cartography with LANDSAT images". Science of the Total Environment. 378, 209-213.

Garcia, D. and Riera, P. (2003). "Expansion versus density in Barcelona: a valuation exercise”. Urban Studies. 40(10), 1925-1936.

Garcia-Lopez, M.-A. and MuÑIZ, I. (2010). "Employment decentralisation: polycentricity or scatteration? The case of Barcelona”. Urban Studies. 47(14), 3035-3056.

Giannakourou, G. (2005). "Transforming spatial planning policy in Mediterranean countries: Europeanization and domestic change". European Planning Studies. 13, 319-331.

Hasse, J. E. and Lathrop, R. G. (2003). "Land resource impact indicators of urban sprawl”. Applied Geography. 23, 159-175.

Jaeger J.A.G., Bertiller R., Schwick C., Cavens D. and Kienast F. (2010). "Urban permeation of landscapes and sprawl per capita: New measures of urban sprawl". Ecological Indicators. 10(2), 427-441

Johnson, M. P. (2001). "Environmental impacts of urban sprawl: a survey of the literature and proposed research agenda". Environment and Planning A. 33(4), 717-735.

Kilic, S., Evrendilek, F., Berberoglu, S. and Demirkesen, A. C. (2006). "Environmental monitoring of land-use and land-cover changes in a Mediterranean region of Turkey". Environmental Monitoring and Assessment. 114, 157-168.

Kucukmehmetoglu, M. and Geymen, A. (2009). "Urban sprawl factors in the surface water resource basins of Istanbul”. Land-use Policy. 26, 569-579.

Marull, J., Pino, J., Tello, E., Cordobilla, M. J. (2010). "Social metabolism, landscape change and land use planning in the Barcelona Metropolitan Region". Land use policy. 27(2), 497-510.

McGregor, D., Simon, D. and Thompson, D. (2006). The peri-urban interface: approaches to sustainable natural and human resource use. London: Earthscan.

Munafò, M., Norero, C., Sabbi, A. and Salvati, L. (2010). "Urban soil consumption in the growing city: a survey in Rome”. Scottish Geographical Journal. 126(3), $153-161$.

NeL·LO, O. (2011a). "Estrategias para la contención y gestión de las urbanizaciones de baja densidad en Cataluña”. Ciudad y territorio. Estudios territoriales. XLIII(167), $81-98$.

- (2011b). "La ordenación de las dinámicas metropolitanas. El Plan Territorial Metropolitano de Barcelona. Scripta Nova”. Revista electrónica de Geografía y Ciencias Sociales. XV(362).

Neuman, M. (2005). "The compact city fallacy". Journal of Planning and Education Research. 25(1), 11-26.

PaüL, V. and Tonts, M. (2005). "Containing urban sprawl: trends in land-use and spatial planning in the Metropolitan Region of Barcelona”. Journal of Environmental Planning and Management. 48(1), 7-35.

Polyzos, S., Christopoulou, O., Minetos, D., and Leal Filho, W. (2008). “An overview of urban-rural land use interactions in Greece". International Journal of Agricultural Resources, Governance and Ecology. 7, 276-296. 
Ramos, M.C., Nacci, S. and Pla, I. (2000). "Soil sealing and its influence on erosion rates for some soils in the Mediterranean area". Soil Science. 165, 398-403.

Reckien, D., Eisenack, K. and Ludeke, K. B. (2011). "Land consumption by urban sprawl - a new approach to deduce urban development scenarios from actors' preferences". Environmental Modeling and Assessment. 16, 465-477.

Salvati, L. (2013a). "From Simplicity to Complexity: The Changing Geography of Land Vulnerability to Degradation in Italy". Geographical Research. 51(3), 318-328.

- (2013b). "Exploring the Spatial Pattern of Soil Sealing in a Mediterranean Periurban Area". Journal of Environmental Planning and Management, in press.

Salvati, L., Sateriano, A. and Bajocco, S. (2013). "To Grow or to Sprawl? Evolving Land Cover Relationships in a Compact Mediterranean City Region”. Cities. 30, 113-121.

Schneider, A. and Woodcock, C. E. (2008). "Compact, dispersed, fragmented, extensive? A comparison of urban growth in twenty-five global cities using remotely sensed data, pattern metrics and census information". Urban Studies. 45(3), 659-692.

Serra, P., Pons, X. and Sauri, D. (2008). "Land-cover and land-use change in a Mediterranean landscape: a spatial analysis of driving forces integrating biophysical and human factors". Applied Geography. 28, 189-209.

Serra, P., Vera, A. and Tulla, A.F. (2013). "Spatial and socio-environmental dynamics of Catalan regional planning from a multivariate statistical analysis using 1980s and 2000s data". European Planning Studies, in press.

Shahraki, S. Z., Sauri, D., Serra, P., Modugno, S., Seifolddini, F. and PourahMAD, A. (2011). "Urban sprawl pattern and land-use change detection in Yazd, Iran”. Habitat International. 35, 521-528.

TsaI, Y. (2005). "Quantifying urban form: compactness versus sprawl”. Urban Studies. 42(1), 141-161.

Villa, P. (2012). "Mapping urban growth using Soil and Vegetation Index and Landsat data: The Milan (Italy) city area case study". Landscape and Urban Planning. 107, 245-254.

Weber, C., Petropoulou, C. and Hirsch, J. (2005). "Urban development in the Athens metropolitan area using remote sensing data with supervised analysis and GIS”. International Journal of Remote Sensing. 26(4), 785-796.

Yilmaz, R. (2010). "Monitoring land use/land cover changes using CORINE land cover data: a case study of Silivri coastal zone in metropolitan Istanbul". Environmental Monitoring and Assessment. 165, 603-615. 